\title{
Using Youtube as a Learning Tool for Basic Volleyball Techniques for Junior High School Students during Pandemic
}

\author{
Ijlal Dhea Syaputra1, Asep Bayu Dani Nandiyanto ${ }^{2, *}$, Tedi Kurniawan ${ }^{3}$, Muhammad \\ Roil Bilad ${ }^{4}$ \\ ${ }^{1}$ Departemen Pendidikan Kesehatan dan Rekreasi, Universitas Pendidikan Indonesia, Indonesia \\ ${ }^{2}$ Departemen Pendidikan Kimia, Universitas Pendidikan Indonesia, Indonesia \\ ${ }^{3}$ Community College of Qatar, Qatar \\ ${ }^{4}$ Faculty of Integrated Technologies, Universiti Brunei Darussalam, Brunei Darusallam \\ *Corresponding author: nandiyanto@upi.edu
}

\begin{abstract}
Abstrak:
Pandemi COVID-19 berdampak besar pada pendidikan di Indonesia. Berbagai upaya dilakukan untuk menarik minat belajar siswa, salah satu upaya yang dilakukan guru adalah video pembelajaran dengan tujuan agar siswa dapat memahami pelajaran dengan baik. Tujuan dari kegiatan ini adalah untuk mengetahui efektivitas aplikasi Youtube sebagai sarana pembelajaran olahraga bagi siswa SMP di masa pandemi. Hasil data kegiatan ini menunjukkan diperoleh $52 \%$ hasil pretest pengetahuan teknik dasar bola voli siswa. Namun setelah pemberian materi dengan video Youtube, hasil post-test pengetahuan meningkat menjadi 84\% ,jadi pembelajaran melalui video Youtube dapat meningkatkan literasi siswa. Oleh karena itu, perlu adanya variasi metode pembelajaran di masa pandemi ini yang diharapkan mampu meningkatkan kualitas literasi siswa.
\end{abstract}

Keywords: Bola Voli, Pandemi, Youtube

\begin{abstract}
:
The COVID-19 pandemic has had a major impact on education in Indonesia. Various efforts were made to attract students' interest in learning, one of the efforts made by the teacher was a learning video with the aim that students were able to understand the lesson well. The purpose of this study was to determine the effectiveness of the Youtube application as a means of learning sports for junior high school students during the pandemic. The results of this activity data show 52\% of the students' basic volleyball knowledge pretest results were obtained. However, after giving the material with Youtube videos, the post-test results of knowledge increased to $84 \%$ so that learning through Youtube videos can improve student literacy. Therefore, there is a need for variations in learning methods during this pandemic which are expected to be able to improve the literacy quality of students.
\end{abstract}

Keywords: Pandemic, Volleyball, Youtube

Volume 2, Nomor 2, Oktober 2021 | 121

Using Youtube as a Learning Tool for Basic Volleyball Techniques for Junior High School Students during pandemic

Ijlal Dhea Syaputra, Asep Bayu Dani Nandiyanto, Tedi Kurniawan, Muhammad Roil Bilad

https://doi.org/10.26874/jakw.v2i2.138 


\section{Introduction}

In the current state of the COVID-19 pandemic, it can affect all aspects or activities in human life, in the economy and education (Hartanti et al., 2021). In fact, currently with the COVID-19 pandemic encouraging all education sectors to conduct online learning, even with positive academic results, students reported increased stress, anxiety and also had difficulty concentrating because they were not used to it (Lemay et al., 2021) The pandemic is a problem that has caused more than 200 countries in the world, including Indonesia, to suppress its spread by implementing a lockdown, improving health services including the availability of personal protective equipment (PPE) and notification of Stay At Home. Indonesia itself has been heavily affected by COVID-19 with a case fatality rate (CFR) of 8.9\%. at the end of March 2020 (Setiati \& Azwar, 2020).

One of the sports learning that is hampered during this pandemic is Volleyball. Volleyball is a team game, this game emphasizes teamwork and cohesiveness in a team. This game uses the arm as a bat and the ball as an object to hit. The elements of motion contained in volleyball games include throwing, swinging, hitting and jumping (Syaleh, 2017)

The application used this time is Youtube. Youtube is a website that is loaded with video sharing and users are allowed to upload, watch and share learning videos. This site is easily accessible by anyone and has provided learning media for various fields of study, including learning, both products from within and outside the country. For this reason, the selective use of learning videos from this site is highly recommended for all teachers to serve and advance physics education in Indonesia. Since its launch as a website for sharing daily videos in 2005, Youtube has become one of the most powerful digital media platforms in the world (Burgess, 2018).

Previous research shows that learning media is needed in the teaching process so that learning can take place easily according to class conditions. Learning videos are suitable learning media and in it there are stages of the learning process that are clearly and in detail. Learning video media can be used as a source of independent learning in sports learning ( Carolin et al., 2020). The results of other studies reveal that Youtube has a significant influence and students view the use of Youtube positively (Winarni \& Rasiban, 2021). Youtube research also shows an increase in student learning motivation (Yusri et al., 2018).

The issue of this pandemic is very influential in the world, especially in the field of education, and we never know when this pandemic will end or when schools will meet again. 
In this case, schools of all levels will always be online and children will learn completely at home. So, we think learning through Youtube media will increase the understanding of sports lessons.

\section{Method}

This study uses a quantitative descriptive research design. The data collection technique uses a questionnaire which we will distribute to 10 students of Junior High School 2 Banjaran. We use this method because we do not use a comparison class as a form of the author's efforts to explain the advantages of a method (Juita \& Yusmaridi, 2018). This observation was carried out online using the WhatsApp application and zoom meeting with 10 children. This activity was conducted using a pretest before the implementation of literacy habituation using video media of basic ball game techniques from Youtube, then after the literacy habituation treatment we gave another post-test to see how and to what extent the development of children's knowledge about basic techniques in volleyball games.

\section{Result and Discussion}

The questionnaire was distributed to principal and teachers of 2 Banjaran Junior High School using WhatsApp application as captured in Figure 1, while learning materials about basic volleyball techniques was delivered to teachers and students of 2 Banjaran Junior High School via Youtube as seen Figure 2. 


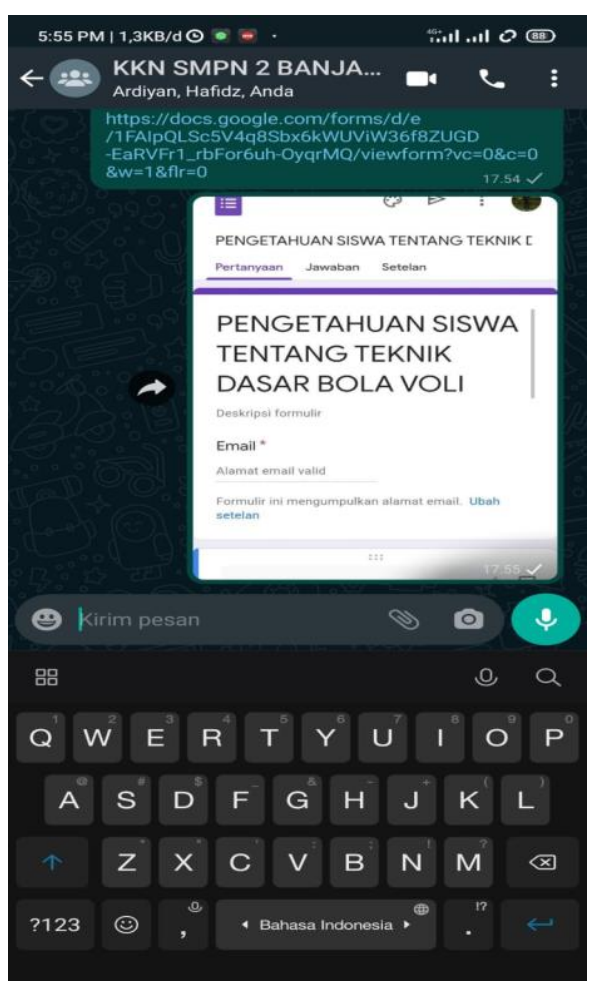

Figure 1. Distribution of questionnaires via WhatsApp.

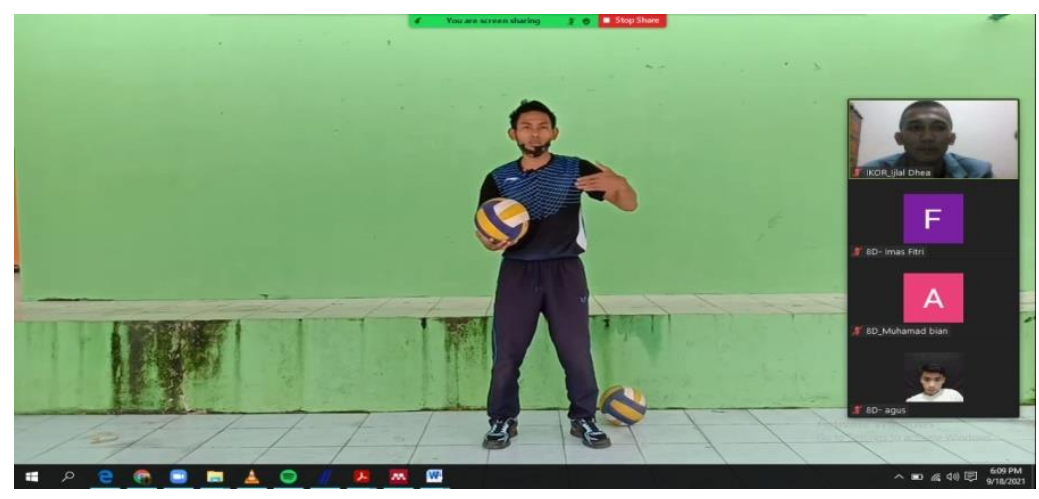

Figure 2. Learning with Student Via Zoom Application

This activity was conducted on eighth grade students of SMP Negeri 2 Banjaran with categories of all genders. We distributed 10 Pre-Test questions to students, provided learning videos from Youtube. Finally, we gave 10 Post-Test questions to determine the extent of students' understanding of the basic techniques of the Volleyball game.

Table 1 shows the responses that have been collected from $8^{\text {th }}$ grade students. The number of samples includes $60 \%$ for male students and $40 \%$ for female students. This activity was conducted online and the media used to collect pre-test and post-test data was google form. Based on the results, it could be inferred as the followings:

(i) For question number 1 all student already know about Volleyball.

Volume 2, Nomor 2, Oktober 2021 | 124 Using Youtube as a Learning Tool for Basic Volleyball Techniques for Junior High School Students during pandemic 
(ii) For question number 2 all students already know about volleying.

(iii) For question number 3 all students already know about bumping.

(iv) For question number 4 there has been an increase of $20 \%$ regarding jumping service.

(v) For question number 5 there has been an increase of $20 \%$ regarding Blocking.

(vi) For question number 6 . there has been an increase of $40 \%$ regarding Spiking.

(vii) For question number 7 there has been an increase of $40 \%$ regarding Setting.

(viii) For question number 8 there has been an increase of $50 \%$ regarding digging.

(ix) For question number 9 all students already know about service.

(x) For question number 10 there has been an increase of 50\% regarding Floating Service.

From Table 1 we get $52 \%$ of the results of the pre-test of students' knowledge of basic volleyball techniques. However, after giving the material with Youtube videos, the post-test results of knowledge increased to $84 \%$. In line with what Kamhar et al (2019) stated, the use of Youtube media was able to have a positive impact for the development of student literacy (Kamhar, M. Y., and Lestari, E. 2019).

Table 1. Pre-test and post-test Result

\begin{tabular}{|c|l|c|c|c|}
\hline no & \multicolumn{1}{|c|}{ Questions } & Pre-test & Post-test & Gain \\
\hline 1 & Do you know Volleyball ? & $100 \%$ & $100 \%$ & $0 \%$ \\
\hline 2 & Do you know the Volleying? & $100 \%$ & $100 \%$ & $0 \%$ \\
\hline 3 & Do you know the Bumping? & $100 \%$ & $100 \%$ & $0 \%$ \\
\hline 4 & Do you know the Jumping Service ? & $80 \%$ & $100 \%$ & $20 \%$ \\
\hline 5 & Do you know the Blocking? & $70 \%$ & $90 \%$ & $20 \%$ \\
\hline 6 & Do you know the Spiking? & $40 \%$ & $80 \%$ & $40 \%$ \\
\hline 7 & Do you know the Setting? & $30 \%$ & $70 \%$ & $40 \%$ \\
\hline 8 & Do you know the Digging? & $0 \%$ & $50 \%$ & $50 \%$ \\
\hline 9 & Do you know the Service? & $100 \%$ & $100 \%$ & $0 \%$ \\
\hline 10 & Do you know the Floating Service? & $0 \%$ & $50 \%$ & $50 \%$ \\
\hline
\end{tabular}

\section{Conclusion}

Based on the results of this activity, the need for varied learning methods to increase students' literacy levels. The results of this study indicate an increase in students' knowledge at the time of the post-test $52 \%$ increased to $84 \%$ after the post-test data was obtained. Varied methods are able to develop children's literacy, one of which is by presenting material through learning videos from Youtube. 


\section{Acknowledged}

We acknowledged Bangdos, Universitas Pendidikan Indonesia. We thank to Nano

Supriyatna, S.Pd from Junior High School 2 Banjaran. This study is a part of Community Service Program Tematik Literasi 2021 from group 21 Lembaga Penelitian dan Pengabdian Masyarakat (LPPM), Universitas Pendidikan Indonesia. We also thank to Kantor Jurnal and Publikasi, Directorate of International Affairs, Universitas Pendidikan Indonesia. We thank to Nissa Nur Azizah, Dwi Fitria Al Hussaeni, S.T., M.Eng., Muktiarni, S.Pd., M.Pd., Rina Maryanti, S.Pd., M.Pd., and Asri Wibawa Sakti, M.Pd.

\section{References}

Burgess, J. and Green, J. 2018. Youtube : Online Video and Participatory Culture. Cambridge: Polity Press.

Carolin, L.L., Astra, I.K.B. \& Suwiwa, I.G. 2020. Pengembangan Media Video Pembelajaran Dengan Model ADDIE Pada Materi Teknik Dasar Tendangan Pencak Silat Kelas VII SMP Negeri 4 Sukasada Tahun Pelajaran 2019/2020. Jurnal Kejaora (Kesehatan Jasmani Dan Olah Raga), 5(2), 12-18.

Hartanti, R. D., Gustiawati, R. \& Abduloh, A. 2021. Pelaksanaan Belajar dari Rumah pada Pembelajaran Bola Voli. Jurnal Ilmiah Wahana Pendidikan, 7(4), 584-591.

Juita, D. \& Yusmaridi, Y. 2018. Pengaruh Kegiatan Kuliah Umum Terhadap Peningkatan Pemahaman Konsep Metodologi Penelitian Mahasiswa Semester 7 Jurusan Tadris Biologi FTIK IAIN. Tarbawi: Jurnal Ilmu Pendidikan, 14(2), 45-50.

Kamhar, M. Y. \& Lestari, E. 2019. Pemanfaatan Sosial Media Youtube Sebagai Media Pembelajaran Bahasa Indonesia di Perguruan Tinggi. Inteligensi: Jurnal Ilmu Pendidikan, 1(2), 1-7.

Lemay, DJ, Bazelais, P., and Doleck, T. 2021. Transition to online learning during the covid19 pandemic. Computers in Human Behavior Reports, 4, 100130.

Setiati, S., and Azwar, M.K. 2020. Covid-19 and Indonesia. Acta Medica Indonesiana, 52(1), 84-89.

Syaleh, M. (2017). Upaya Meningkatkan Hasil Belajar Servis Atas Bola Voli Melalui Media Pembelajaran Lempar Pukul Bola Kertas pada Siswa Kelas VII SMP. Jurnal Prestasi, 1(1).

Winarni, R. S., \& Rasiban, L. M. 2021. Perception of Japanese students in using online video as a learning media. Indonesian Journal of Educational Research and Technology, 1(1), 15-16.

Yusri, Y., Rosida, A., Jufri, J., \& Mantasiah, R. 2018. Efektivitas Penggunaan Media Youtube Berbasis Various Approaches dalam Meningkatkan Motivasi Belajar Bahasa Inggris. Eralingua: Jurnal Pendidikan Bahasa Asing dan Sastra, 2(2). 